Matematikai Közlemények

VI. kötet, 2018

doi:10.20312/dim.2018.05

\title{
Kettős Awrami függvény alkalmazása
}

\author{
Csanády Viktória \\ SOE Matematikai Intézet \\ csanady.viktoria@uni-sopron.hu
}

\begin{abstract}
ÖSSZEFOGLALÓ. Az időbeli folyamatok, összefüggő fizikai, biológiai jellemzők kapcsolatának regressziós vizsgálata során a statisztikai programok adta lehetőségek végett, számos bonyolult matematikai modell alkalmazására nyílik mód. Az alábbiakban egy speciális modell kerül bemutatásra, annak sokoldalúságát kiemelve, példákkal illusztrálva.

ABSTRACT. Statistical programs enabled us to apply several complex mathematical models for regression analysis in the investigation of the relationships of physical and biological properties in time processes. In what follows, we present a special model and emphasize its versatility by introducing examples.
\end{abstract}

\section{Bevezetés}

A regressziós elemzések esetén a számítógépes statisztikai programok lehetőséget kínálnak arra, hogy viszonylag bonyolult modellek kerüljenek alkalmazásra, melyek a folyamatot nemcsak megfelelő pontossággal írják le, hanem számos feltételnek is eleget tesznek. Érdekes talán megemlíteni, hogy az úgynevezett exponenciális görbék alkalmazásával - és itt nem a hagyományos értelemben vett exponenciális függvényről van szó - már a XIX században is foglalkoztak, például különböző biológiai folyamatok leírásánál. Ezeket a függvényeket lehetne az Awrami függvény elődjeinek nevezni, amely függvények kezdetleges telítési modelleknek tekinthetők. Mivel illesztésük meglehetösen számolásigényes és bonyolult müvelet volt, alkalmazásuk nem igazán terjedt el. Napjainkban viszont újra felfedezték a telítési modelleket és egyre gyakoribb a használatuk a már említett kedvező tulajdonságaik végett - a teljesség igényétől eltekintve csak néhány ezek közül zérusból indítható, korlátos, aszimptotikus. Az említett függvénytípusok kedvező felhasználhatósága további modellfejlesztésekre ösztönöz, így került sor egy olyan modell létrehozására, ami két eltolt helyzetü Awrami függvény szuperponáltja. Az alábbiakban bemutatásra kerül az alkalmazott modell, valamint néhány konkrét alkalmazás, melyhez a vizsgált adatsor a Központi Statisztikai Hivatal adatbázisából került kiválasztásra.

A vizsgálat az 1995-2017 éves időszak egyes éveiben felmért teljes juh, sertés és szarvasmarha állomány adatainak statisztikai regressziós elemzésére terjedt ki. Az adatok az 1. táblázat: Állatlétszám tartalmazza.

A vizsgált adathalmaz és az alkalmazott modell. A lehetséges kutatás végett, törekedve a teljességre az alábbiakban bemutatásra kerül a vizsgált adatsor. A táblázat első oszlopában az évek, első sorában a sorszámozott vizsgálati adatsorok kerültek feltüntetésre. Így:

1: Juh állomány.

2: Sertés állomány.

3: Szarvasmarha állomány.

KuLCSSZAVAK. Regresszió, speciális Awram függvény, nem lineáris regresszió.

KEYWORDS. Regression, special Awrami function, nonlinear regression. 


\begin{tabular}{|c|c|c|c|c|}
\hline & $\begin{array}{l}1 \\
\text { Év }\end{array}$ & $\begin{array}{c}2 \\
\text { Juh (ezer) }\end{array}$ & $\begin{array}{c}3 \\
\text { Sertés } \\
\text { (ezer) }\end{array}$ & $\begin{array}{c}4 \\
\begin{array}{c}\text { Szarvasmarha } \\
\text { (ezer) }\end{array}\end{array}$ \\
\hline 1 & 1995 & 977 & 5032 & 421 \\
\hline 2 & 1996 & 872 & 5289 & 414 \\
\hline 3 & 1997 & 858 & 4931 & 403 \\
\hline 4 & 1998 & 909 & 5479 & 407 \\
\hline 5 & 1999 & 934 & 5335 & 399 \\
\hline 6 & 2000 & 1129 & 4834 & 380 \\
\hline 7 & 2001 & 1136 & 4822 & 368 \\
\hline 8 & 2002 & 1103 & 5082 & 362 \\
\hline 9 & 2003 & 1296 & 4913 & 350 \\
\hline 10 & 2004 & 1397 & 4059 & 345 \\
\hline 11 & 2005 & 1405 & 3853 & 334 \\
\hline 12 & 2006 & 1298 & 3987 & 322 \\
\hline 13 & 2007 & 1232 & 3871 & 322 \\
\hline 14 & 2008 & 1236 & 3383 & 324 \\
\hline 15 & 2009 & 1223 & 3247 & 312 \\
\hline 16 & 2010 & 1181 & 3169 & 309 \\
\hline 17 & 2011 & 1120 & 3044 & 329 \\
\hline 18 & 2012 & 1185 & 2989 & 339 \\
\hline 19 & 2013 & 1214 & 3004 & 345 \\
\hline 20 & 2014 & 1185 & 3135 & 359 \\
\hline 21 & 2015 & 1190 & 3124 & 368 \\
\hline 22 & 2016 & 1141 & 2907 & 383 \\
\hline 23 & 2017 & 1146 & 2870 & 395 \\
\hline
\end{tabular}

1. táblázat. Állatlétszám

Az alkalmazott regressziós modell

- hagyományos matematikai alakja:

$$
y=b_{8}-b_{7} \cdot e^{\left(-1 \cdot\left(b_{6} \cdot\left(x-b_{5}\right)\right)^{b_{4}}\right)}-b_{3} \cdot e^{\left(-1 \cdot\left(-1 \cdot b_{2} \cdot\left(x-b_{1}\right)\right)^{b_{0}}\right)}
$$

- a számítógépes alak:

$\operatorname{var} 2=\mathrm{b} 8-\mathrm{b} 7 * \exp \left(-1 *(\mathrm{~b} 6 *(\operatorname{var} 1-1 * \mathrm{~b} 5))^{\wedge} \mathrm{b} 4\right)-\mathrm{b} 3 * \exp \left(-1 *(-1 * \mathrm{~b} 2 *(\operatorname{var} 1-1 * \mathrm{~b} 1))^{\wedge} \mathrm{b} 0\right)$.

\section{Kezdöértékek meghatározása.}

b8=a maximális vagy minimális var2 érték,

b7=a maximális vagy minimális var2 érték mínusz a kezdő var2 érték, b6=a var1 nagyságrend reciproka, az esetek többségében $0,1(0,05)$,

b5=a var1 kezdőértéke, vagy annál relatív kisebb,

b4=az esetek többségében 3 (5),

b3 =a maximális vagy minimális var2 érték mínusz a végső var2 érték,

b2=a var1 nagyságrend reciproka, az esetek többségében $0,1(0,05)$,

b1=a var1 végsőértéke, vagy annál relatív nagyobb,

b0 $=$ az esetek többségében 3 (5). 
A modell levezetése.

Az alkalmazott függvény egy normál helyzetủ transzformált és egy y-tengelyre tükrözött megfelelően transzformált Awrami függvény összegéből került kialakításra, zárt értelmezési tartomány feltételével. A modell levezetése megtalálható Csanády V.: Gazdasági változások regressziós vizsgálata c. cikkében (Dimenziók 2017).

Az alkalmazott modell rendkívüli rugalmasságát néhány kísérleti adatsorra történő illesztés igazolja. Az illesztéseknél alkalmazott adatsorok nem kerülnek feltüntetésre, ahogy a kapott paraméterek értékeinek táblázata sem. A korrelációs együttható minden esetben meghaladta a 0,995-ös értéket, ami szoros korrelációra utal. A már említett rugalmasságot legszemléletesebben a kapott regressziós modellek ábrája mutatja. Az alábbi 1. ábra: Modellek kilenc különbözö adatsorra történt illesztés regressziós modelljének grafikonját mutatja. Az ábra önmagáért beszél, igazolva a modell hihetetlen rugalmasságát, amit a kilenc paraméter értékének változatossága okozza.

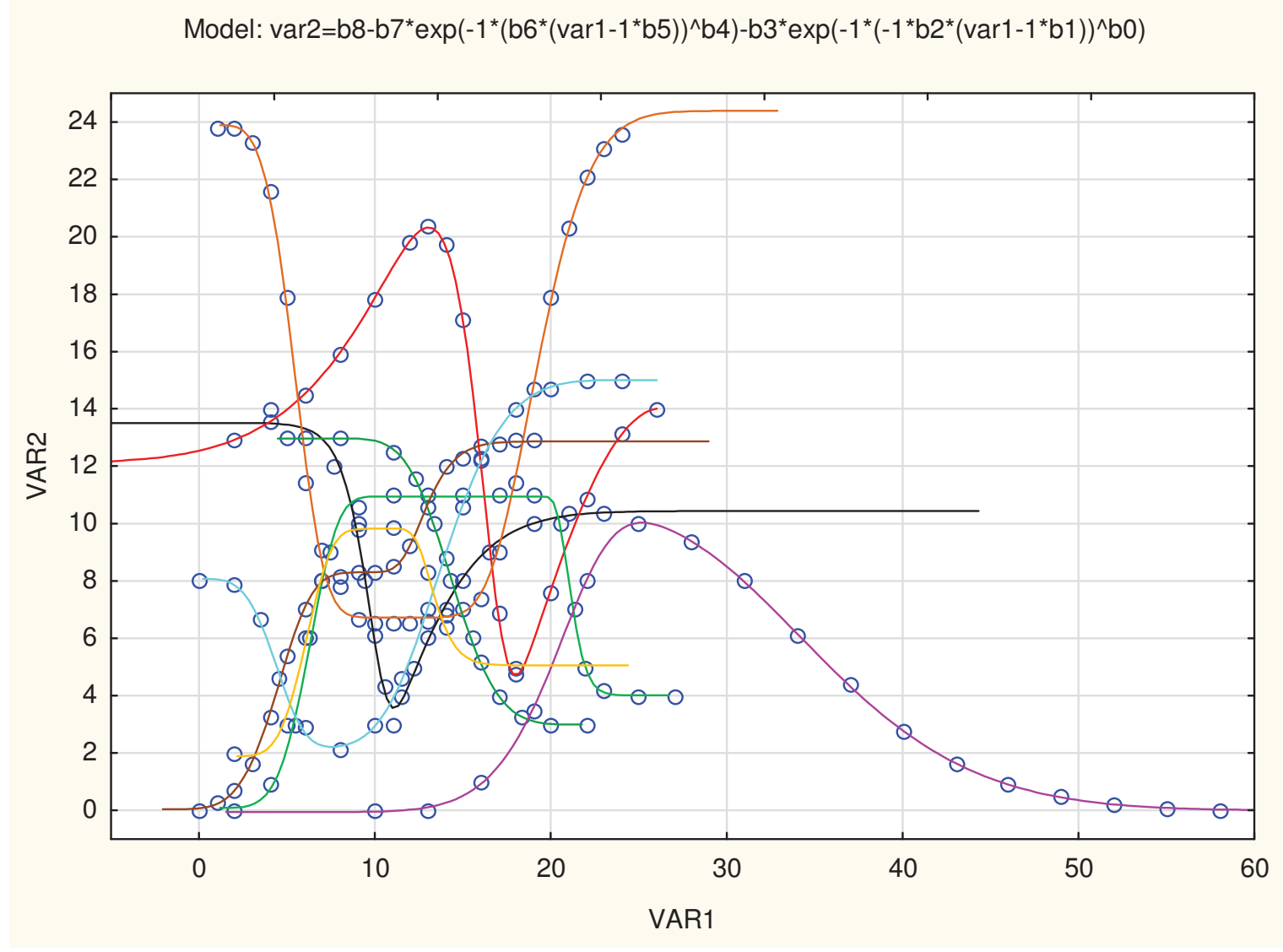

1. ábra. Modellek 


\section{Számított eredmények, kiértékelés}

\subsection{A regressziós eljárással nyert eredmények}

A már említett Központi Statisztikai Hivatal adatbázisából letöltött adatokra történő illesztés eredményét és azok grafikonjait az alábbiak mutatják.

Model: var2=b8-b7*exp $\left.\left(-1^{*}\left(\mathrm{~b} 66^{*}\left(\operatorname{var} 1-1^{*} \mathrm{~b} 5\right)\right)\right)^{\wedge} \mathrm{b} 4\right)-\mathrm{b} 3^{*} \exp \left(-1^{*}\left(-1^{*} \mathrm{~b} 2^{*}\left(\operatorname{var} 1-1^{*} \mathrm{~b} 1\right)\right)^{\wedge} \mathrm{b} 0\right)$

$\mathrm{y}=(3315,3)-(2420,79)^{\star} \exp \left(-1^{*}\left((0,0811225)^{\star}\left(\mathrm{x}-1^{*}(1990,48)\right)\right)^{\wedge}(9,03982)\right)-(2137,7)^{\star} \exp \left(-1^{*}\left(-1^{*}(0,0208062)^{\star}(x\right.\right.$ $\left.(2050,09)))^{\wedge}(33,0691)\right)$

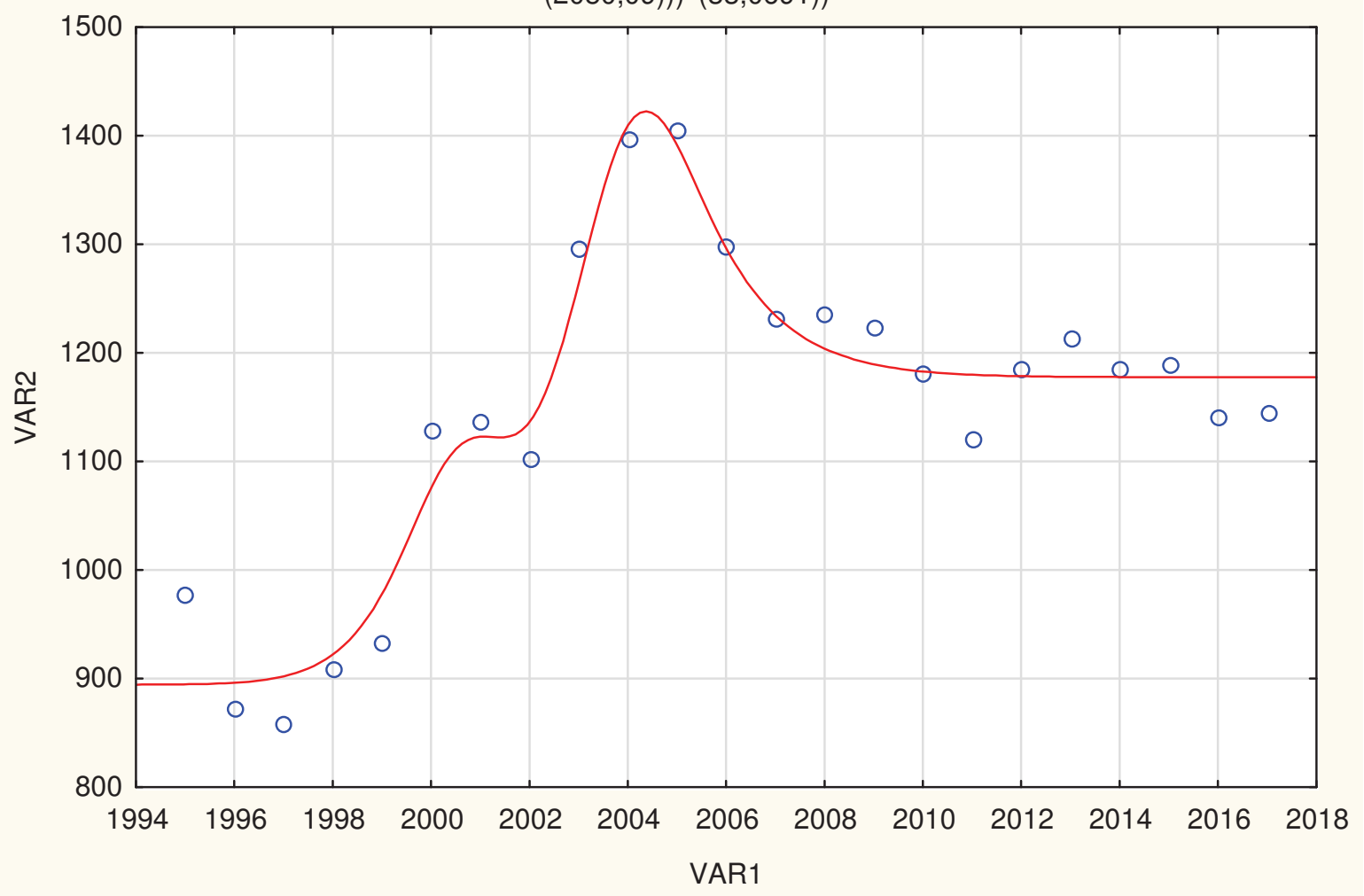

2. ábra. Juh állomány

\begin{tabular}{|c|c|c|c|c|c|c|c|c|}
\hline \multirow[b]{2}{*}{$\mathrm{N}=23$} & \multicolumn{8}{|c|}{ 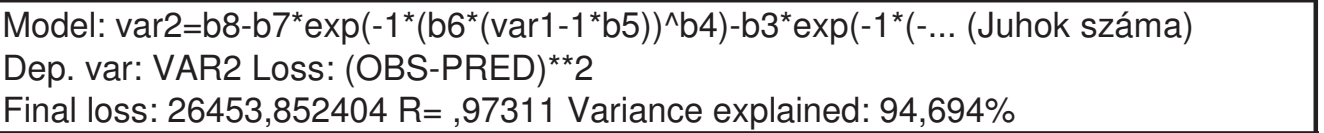 } \\
\hline & $\mathrm{b} 8$ & b7 & $\mathrm{b} 6$ & b5 & b4 & b3 & b2 & $\mathrm{b} 1$ \\
\hline Estimate & 3315,29 & 2420,78 & 0,08112 & 1990,47 & 9,03982 & 2137,70 & 0,02080 & 2050,09 \\
\hline
\end{tabular}

2. táblázat. Juh állomány 
Model: var2=b8-b7*exp $\left(-1^{*}\left(\mathrm{~b} 6^{*}\left(\operatorname{var} 1-1^{*} \mathrm{~b} 5\right)\right)^{\wedge} \mathrm{b} 4\right)-\mathrm{b} 3^{*} \exp \left(-1^{*}\left(-1^{*} \mathrm{~b} 2^{*}\left(\operatorname{var} 1-1^{*} \mathrm{~b} 1\right)\right)^{\wedge} \mathrm{b} 0\right)$

$y=(5264,32)-(2473,76)^{\star} \exp \left(-1^{\star}\left((0,253323)^{\star}\left(x-1^{*}(1988,79)\right)\right)^{\wedge}(1,98179)\right)-(2289,13)^{\star} \exp \left(-1^{*}\left(-1^{*}(0,0616665)^{\star}(\right.\right.$ $\left.*(2019,97)))^{\wedge}(4,86094)\right)$

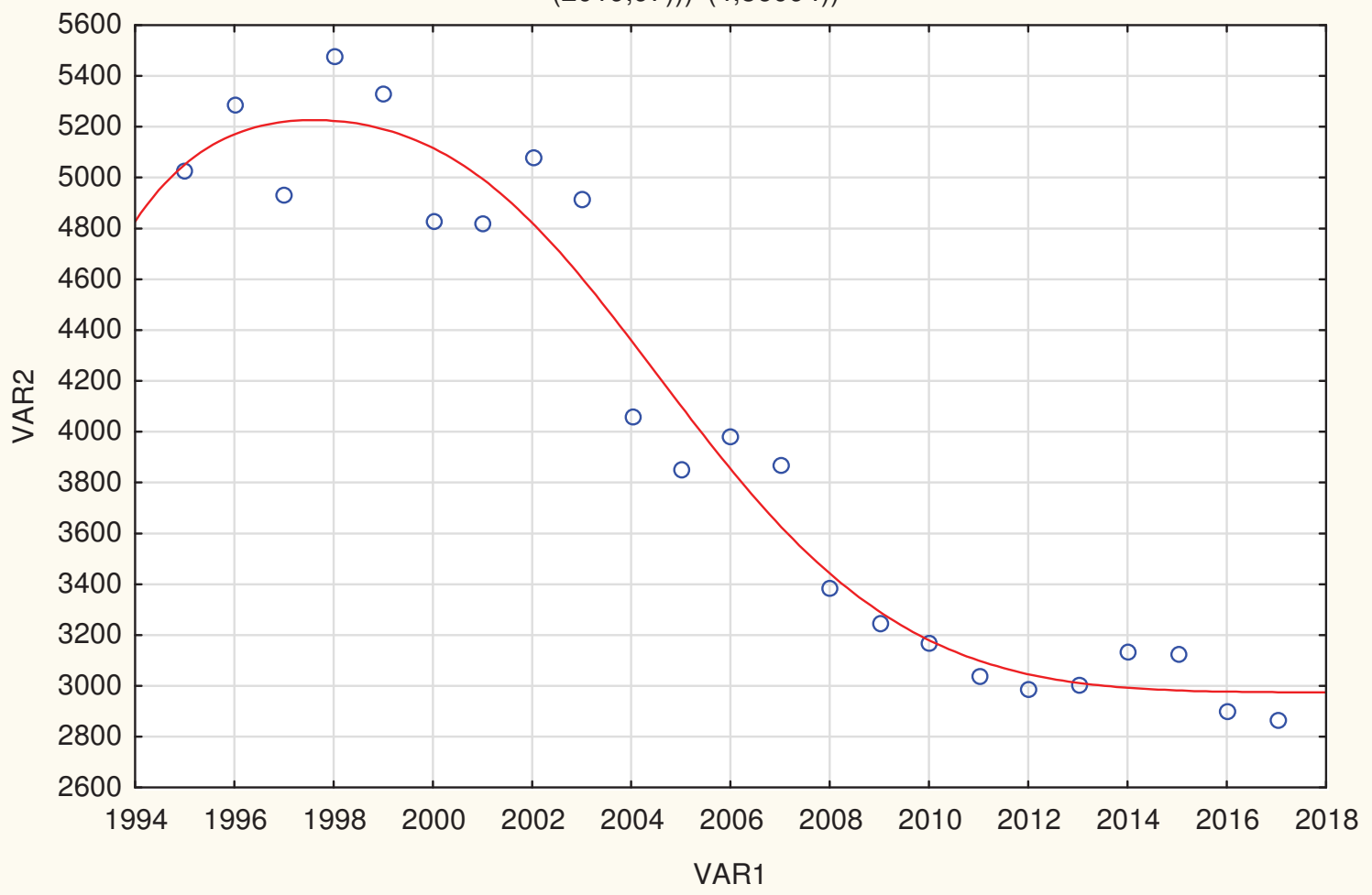

3. ábra. Sertés állomány

\begin{tabular}{|c|c|c|c|c|c|c|c|c|}
\hline \multirow[b]{2}{*}{$N=23$} & \multicolumn{8}{|c|}{ 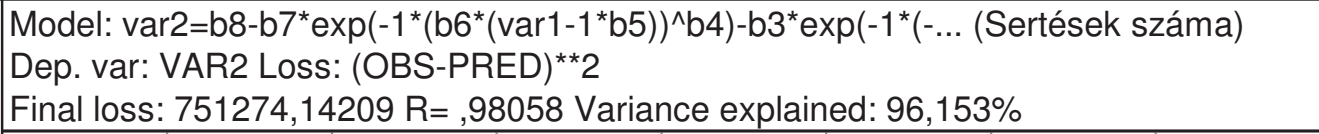 } \\
\hline & b8 & b7 & b6 & b5 & b4 & b3 & b2 & b1 \\
\hline Estimate & 5264,32 & 2473,75 & 0,25332 & 1988,79 & $1,9817 \mathrm{C}$ & 2289,12 & 0,06166 & 2019,97 \\
\hline
\end{tabular}

3. táblázat. Sertés állomány 


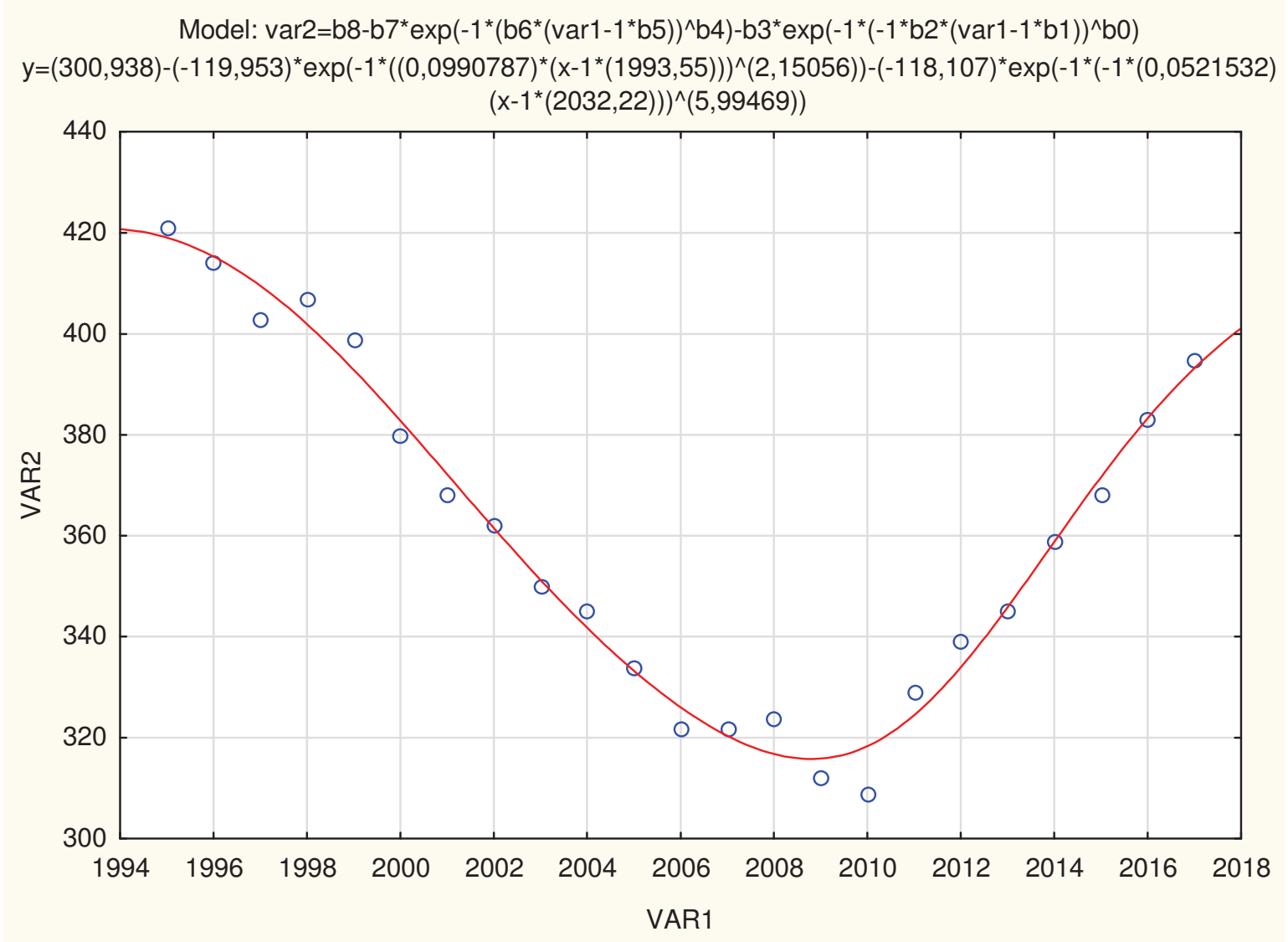

4. ábra. Szarvasmarha állomány

\begin{tabular}{|c|c|c|c|c|c|c|c|c|}
\hline \multirow[b]{2}{*}{$\mathrm{N}=23$} & \multicolumn{8}{|c|}{$\begin{array}{l}\text { Model: var2=b8-b7*exp }\left(-1^{*}\left(\mathrm{~b} 6^{*}\left(\mathrm{var} 1-1^{*} \mathrm{~b} 5\right)\right)^{\wedge} \mathrm{b} 4\right)-\mathrm{b} 3^{*} \exp \left(-1^{*}(-\ldots(\text { Szarvasmarhák száma })\right. \\
\text { Dep. var: VAR2 Loss: (OBS-PRED)**2 } \\
\text { Final loss: } 386,33192451 \mathrm{R}=, 99260 \text { Variance explained: } 98,526 \%\end{array}$} \\
\hline & b8 & b7 & b6 & b5 & b4 & b3 & b2 & b1 \\
\hline Estimate & 300,937 & $-119,95$ & 0,09907 & 1993,54 & 2,15055 & $-118,10$ & 0,05215 & 2032,21 \\
\hline
\end{tabular}

5. táblázat. Szarvasmarha állomány

\subsection{Elemzés, értékelés}

A regressziós vizsgálat elemzése és kiértékelése állományonként a következő:

\section{Juh állomány}

Az illesztés eredményéből a következő alapvető megállapítások tehetők:

1.) A kapott $\mathrm{R}=0,97311$ érték jelzi az időbeli folyamat bizonyos időszakonként ingadozó jellegét.

2.) A függvénygörbe három alapvetően eltérö jellegü időbeli folyamatot mutat.

3.) Az első tartomány az 1995-2001 év időszaka, jól jelzett erősödő növekedéssel, az inflexió elérésével. 
4.) A második tartomány a 2001-2005 év intenzív növekedéssel és, maximum elérésével.

5.) A harmadik tartomány a 2005-2017 év erösen ingadozó gyengülő csökkenéssel , a végső érték továbbiakban maradandó előjelzésével.

\section{Értékelés:}

A fentiek igazolják, hogy az alkalmazott függvény, hasonló jellegü adatsorok vizsgálatára egyszerüen alkalmazható, és teljes körü pontos, részletes tájékoztatást ad.

\section{Sertés állomány}

Mivel a nyert paraméterek között a b4=1,9818 jóval kisebb mint 3, ezért a fentebb bemutatott értékek alapján elsősorban a görbe részletes elemzése segítségével tehetők a következő megállapítások:

1.) Az 1995-2017 időszakban legnagyobb sertéslétszám időpontja var1max=1998 év, mértéke var2max $=5240$ ezer fö.

2.) Az 1995-2017 időszakban a kezdőlétszám időpontja var1kez=1995 év, mértéke var2kez=5030 ezer fö.

3.) Az 1995-2017 időszakban a végsőlétszám időpontja var1vég=2017 év, mértéke var2vég=2960 ezer fö.

4.) Az 1995-1998 időszakban kismértékű létszámnövekedés mutatkozik 5240-5030=210 ezer fővel.

5.) Az 1998-2013 időszakban monoton létszámcsökkenés mutatkozik 5240-3000=2240 ezer fővel.

6.) A 2013-2017 időszakot bizonytalan kisebb mérték létszámingadozás jellemez 130 ezer fövel.

7.) A korrelációs együttható értéke szoros kapcsolatra utal R=0,98058.

Értékelés:

A választott függvény kiemelkedő pontosságú illeszkedése a vizsgált folyamatról részletes tájékoztatást ad. A felsorolt megállapítások összefoglalóan jelzik a sertésállomány nagymértékü csökkenését az 1995-2017 évi időszakban.

\section{Szarvasmarha állomány}

A nyert görbe és paraméterek részletes értékelése alapján a következő alapvető meghatározások tehetők:

1.) A R=0,9926 érték a görbeillesztés kiemelkedő pontosságát jelzi.

2.) Az 1995-2009 éves időszakban az állomány létszáma 419 ezerről 316 ezerre csökkent ingadozás nélküli folyamattal.

3.) A tehénállomány létszáma a minimumot a 2009-2010-es évben érte el 316 ezer értékkel ingadozás jelleggel.

4.) A 2010-2017 éves időszakban az állomány létszáma 316 ezerről 392 ezerre növekedett ingadozás nélküli folyamattal.

5.) A kapott b1=2032 paraméter a függvény matematikai jellege miatt 2017 utáni időszakra még növekedést jelez.

6.) A b6*b4 és b2*b0 kapott paraméter értékek alapján megállapítható, hogy a létszámnövekedés az intenzívebb.

7.) A korrelációs együttható értéke szoros kapcsolatra utal R=0,99260.

Értékelés:

A fentiek igazolják, hogy az alkalmazott függvény, különböző jellegü adatsorokra egyszerủen, kedvezően és nagy pontossággal illeszthető, kiemelkedő rugalmassága miatt. 


\section{3. Összefoglaló}

A bemutatásra került adatsorok különbözősége jól mutatja az összegzett Awrami függvény sokoldalú használhatóságát, annak rugalmassága végett. A magas korrelációs együttható érték jelzi az illesztés pontosságát. A paraméter értékek alapján fontos jellemzők számíthatók, a függvény jól mutatja az adathalmaz egyes szakaszainak menetét, a szélsőértékek esetleges inflexiós pontok behatárolhatok megfelelö pontossággal. Mindezen ismeretek arra utalnak, hogy a függvény alkalmazása szélsőséges adatsorok esetén is indokolt.

\section{Irodalomjegyzék}

[1] Csanády V., Horváth-Szováti E., Szalay L., Alkalmazott statisztika, Sopron, Nyugat-Magyarországi Egyetem Kiadó (2013), 175p.

[2] Csanády V., Gazdasági változások regressziós vizsgálata, Dimenziók V. (2017), 39-49. doi:10.20312/dim.2017.06

[3] Központi Statisztikai Hivatal. https://www.ksh.hu/stadat 